\title{
Disordered eating and body change behaviours: support for the Tripartite Influence Model among Brazilian male university students
}

\author{
Comportamentos de risco para transtornos alimentares \\ e de mudança corporal: suporte ao Modelo dos Três Fatores \\ para adultos brasileiros
}

Pedro Henrique Berbert de Carvalho (https://orcid.org/0000-0002-4918-5080) ${ }^{1}$

Maria Elisa Caputo Ferreira (https://orcid.org/0000-0002-3294-7560) ${ }^{2}$

${ }^{1}$ Universidade Federal de Juiz de Fora (UFJF). R. São Paulo 745, Centro. 35010180 Governador Valadares MG Brasil.

pedro.berbert@ufjf.edu.br ${ }^{2}$ Instituto de Ciências Humanas, Faculdade de Educação Física, UFJF. Juiz de Fora MG Brasil.

\begin{abstract}
The Tripartite Influence Model posits that sociocultural influences mediated by internalization and social comparison are predictors of disordered eating and body change behaviours. This study aimed to test the Tripartite Influence Model among Brazilian male university students, which has not been tested yet. 707 undergraduate students of the five Brazilian regions, completed measures of sociocultural influences, internalization, social comparison, body and muscularity dissatisfaction, disordered eating and body change behaviours. Structural equation modelling analyses showed good model-fitting. Parental influence was related to internalization, while peer influence with social comparison. Media influences were related to both internalization and social comparison. Internalization and social comparison are mediating variables that are related to body dissatisfaction and muscularity dissatisfaction. Finally, muscularity dissatisfaction was associated with body change behaviours.
\end{abstract}

Key words Body image, Feeding and eating disorders, Men's health, Risk factors
Resumo O modelo de influência dos três fatores indica que as influências socioculturais, mediadas pela internalização e a comparação social, são preditoras de comportamentos de risco para transtornos alimentares e comportamentos de mudança corporal. O estudo objetivou testar o Modelo de Influência dos Três Fatores para jovens adultos brasileiros, uma vez que o mesmo ainda não foi testado neste contexto. 707 homens, jovens universitários das cinco regiões brasileiras, responderam a instrumentos de avaliação das influências socioculturais, internalização, comparação social, insatisfação com o corpo e com a muscularidade, comportamentos de risco para transtornos alimentares e comportamentos de mudança corporal. Análise por meio de Modelagem de Equações Estruturais demonstrou adequados índices de ajustamento do modelo. As influências dos pais foram associadas com a internalização, enquanto as influências dos pares com a comparação social. Influência da mídia demonstrou associação tanto com a internalização quanto com a comparação social. A internalização e a comparação social são variáveis mediadoras que se relacionam com a insatisfação corporal e insatisfação com a muscularidade. Por fim, a insatisfação com a muscularidade esteve associada com os comportamentos de mudança corporal.

Palavras-chave Imagem corporal, Transtornos da alimentação e da ingestão de alimentos, Saúde do homem, Fatores de risco 


\section{Introduction}

Research has demonstrated an array of negative consequences associated with body image disturbance and eating pathology such as poor self-esteem and unhealthy weight control practices $^{1,2}$, poor impulse control and social anxiety ${ }^{3}$, and abuse of anabolic androgenic steroids $s^{4,5}$. Researchers have consequently sought to understand the aetiology and maintenance of these disorders to illuminate potential points of intervention ${ }^{2,6}$.

To assess the risk factors associated with the development of disordered eating among women, Thompson et al. ${ }^{7}$ developed the Tripartite Influence Model, which is based on sociocultural theories of body image disturbances and disordered eating ${ }^{8,9}$. This model posits that individuals are pressured by powerful social agents (e.g., parents, peers, and the media) to adhere to culturally sanctioned appearance ideals, which is mediated by the internalization of social body-ideal and appearance social comparison behaviours. Internalization is the process of adopting a body ideal created by society as one's own standards and body goal ${ }^{7,10}$, whereas social comparison denotes the frequent behaviour of self-evaluation using other individuals as a basis of comparison ${ }^{11,12}$.

There is a historical relationship between studies on body image disturbance and eating disorders in the female population, which has contributed to the belief that men would be free from these disorders ${ }^{13,14}$. Strother et al. ${ }^{15}$ argue that eating disorders in males are underdiagnosed, undertreated, and misunderstood.

However, in recent years there has been a considerable increase in the number of research studies on body image and eating disorders in men. Researchers have shown that body image disturbances are also present in men, and they are concerned with acquiring more muscle mass and attaining a more defined body $y^{16,17}$. The drive for muscularity appears to be the major male body image concern ${ }^{13,14,16}$. However, both women and men may be concerned with both body weight and muscularity. The drive for thinness and the drive for muscularity are not mutually exclusive constructs ${ }^{18,19}$.

Although male body image has received considerably less research attention, extant studies indicate that internalization of the muscular-ideal is significantly associated with increased body dissatisfaction, negative affect, and unhealthy behaviours aimed at increasing muscle size ${ }^{12,16,20}$. In turn, social comparison is significantly asso- ciated with muscularity dissatisfaction and body change behaviours ${ }^{12,20}$. Body change behaviours may be understood as adopted strategies in an attempt to achieve an idealized physical appearance, such as the abuse of anabolic androgenic steroids and food supplements, and excessive practice of physical exercise with the goal of increasing muscle mass ${ }^{4,5,17,21}$.

In view of this discussion, it is necessary to evaluate specific theoretical models to understand body image disturbance, disordered eating and body change behaviours in men. It reiterates the fact that male body image and eating disorders in the population must be investigated. Moreover, the Tripartite Influence Model was also evaluated with adolescent $\operatorname{men}^{22,23}$ and young adults ${ }^{12,20,24}$.

Van den Berg et al. ${ }^{24}$ posit that the model is valid to understand body image disturbance in men; however, the authors highlighted the need to further examine processes that are involved in the development of body dissatisfaction in males. Methodological concerns should be considered with respect to the evaluation of the Tripartite Influence Model in men, such as the use of specific measurement instruments for the male population $^{20}$. Moreover and according to Karazsia and Crowther ${ }^{20}$, the Tripartite Influence Model is a robust aetiological model, particularly when constructs are assessed in ways that are reliable and valid for this population.

More recently, Karazsia and Crowther ${ }^{12}$ re-evaluated the Tripartite Influence Model, including a new variable: body change behaviours. In this study, body change behaviours were conceptualized as the practice of excessive physical exercise to the point of causing muscular injury and behaviours oriented towards muscular gain, such as the use of dietary supplements and high protein intake. The final model was similar to the original model proposed by Thompson et al. ${ }^{7}$, which included a relational path between Internalization and Social Comparison. It should also be noted that a direct relational path between social influence factors and body change behaviours was verified, which indicates that parents, peers and the media may exert a strong influence on these behaviours, regardless of the influence of internalization or social comparison ${ }^{12}$.

The Tripartite Influence Model has been evaluated in different countries with various cultural backgrounds, including Brazilian adolescents ${ }^{25}$ and young adult women ${ }^{8}$; however, the model validity has not been tested with Brazilian male university students. The model's validation by 
the previously cited studies does not exempt it from testing for use with the Brazilian male population. The incidence and extent of body dissatisfaction and disordered eating are culturally specific and has gender bias; therefore, specific attention should be paid to cultural and gender characteristics in evaluating these variables ${ }^{26}$.

A population-based study conducted in Bra$\mathrm{zil}^{27}$ indicated a prevalence of $60.5 \%$ of body dissatisfaction in men. Risk behaviours for eating disorders are present in $15.4 \%$ of Brazilian male university students ${ }^{28}$. A perfect, athletic and young body is the main ideological concern in the Brazilian population ${ }^{29}$. Edmonds ${ }^{30}$ suggested that physical appearance is an essential element in the construction of a national Brazilian identity.

Considering the importance of physical appearance for Brazilian men and the influence of cultural aspects on body image disturbance and disordered eating, the present study aimed to evaluate a revised version of the Tripartite Influence Model of disordered eating and body change behaviours among Brazilian male university students. In general, we hypothesized that the proposed model would be valid and reliable for use with Brazilian male university students.

\section{Method}

\section{Participants}

An online calculator that consisted of implementing the guidelines of Westland ${ }^{31}$ was used to determine sample size. The effect size was estimated at .10 based on previous sociocultural model among Brazilian female university students $^{8}$. With this effect size, power of .80 , nine latent variables and 82 observed variables, and $5 \%$ significance level ${ }^{31}$, the minimal sample size to detect an effect was calculated to be equal to 666 individuals.

Seven hundred seven $(\mathrm{N}=707)$ Brazilian male university students, aged 21-35 years $\left(\mathrm{M}_{\mathrm{ag}}\right.$ $=23.98$, standard deviation $(\mathrm{SD})=4.07)$, participated in this study. Thus, our sample size was sufficient to test the hypothesized model. As a basic assumption for applying the statistical method to test the theoretical model (Structural Equation Modelling) $)^{32}$, a heterogenic sample was used. Participants were recruited by convenience after being contacted by associated researchers (research groups, co-workers, past partnerships) in higher education institutions from Brazil's five regions (South, Southeast, Centre-West, North, and Northeast).

Male university students enrolled in Mathematical, Human, Applied Social and Health Sciences participated in the study. In total, individuals from 15 states (Acre, Amapá, Bahia, Espírito Santo, Goiás, Minas Gerais, Pará, Pernambuco, Rio de Janeiro, Rio Grande do Sul, Rondônia, Santa Catarina, São Paulo, Sergipe and Tocantins) distributed in 20 Brazilian cities from 35 different undergraduate courses took part in the present study.

\section{Measures}

Sociodemographic data. In order to characterize the sample, a sociodemographic questionnaire was used, which investigates the information on racial/ethnic background, anthropometry (self-reported stature and body mass for the calculation of body mass index) and socioeconomic family status. Regarding the classification of racial/ethnic background, the categories suggested by the Brazilian Institute of Geography and Statistics ${ }^{33}$ was used, and for the anthropometric nutritional status the categories suggested by the World Health Organization ${ }^{34}$ was used. The socioeconomic family status was evaluated by the Brazilian Economic Classification Criterion ${ }^{35}$.

Sociocultural influences. The Brazilian validated version of the Tripartite Influence Scale (TIS $)^{36}$ was used to assess the influences of parents, peers, and the media on body image. The TIS consists of 39 items with a 5-point Likert scale $(1=$ always to $5=$ never $)$ and total scores that range from 39 to 195 . Three separate subscales were also used: parental influences, peer influences and media influences. The scores for the subscales were inverted to bring them in line with the other scales applied in the present study (i.e., a higher score indicated a greater influence of the "phenomenon" in question).

Internalization. The general internalization and athletic internalization subscales of the Brazilian validated version of the Sociocultural Attitudes Towards Appearance Questionnaire-3 (SATAQ-3 $)^{37}$ were used to evaluate internalization of the social body-ideal. These two subscales total 11 self-reported items rated on a 5-point Likert scale $(1=$ totally disagree to $5=$ totally agree $)$ and total scores that range from 11 to 55 , with higher scores indicating higher internalization.

Social comparison. The relative items (seven) of the Brazilian version of the Male Body Checking Questionnaire (MBCQ) ${ }^{38}$ were used 
to evaluate social comparison. Items are rated on a 5 -point Likert scale $(1=$ never to $5=$ very often), and total scores range from 7 to 49 . A higher score indicates a higher frequency of social comparison.

Body dissatisfaction. The Brazilian validated short version of the Body Shape Questionnaire $(\mathrm{BSQ})^{39}$ was used to evaluate concern with weight and shape. The short version of the BSQ consists of eight items rated with a 6-point Likert scale (1 $=$ never to $6=$ always) and total scores that range from 8 to 48. A greater score indicates a greater level of body dissatisfaction.

Muscularity dissatisfaction. The oriented body image factor of the Brazilian version of the Drive for Muscularity Scale (DMS) ${ }^{40}$ was used to evaluate muscularity dissatisfaction. The five items are rated on a 6-point Likert scale $(1=$ always and $6=$ never), and total scores range from 5 to 30 . The scores of each item were inverted to calculate the final score, in which a greater score indicates greater muscularity dissatisfaction.

Body change behaviours. The muscularity oriented-behaviour factor of the Brazilian version of the $\mathrm{DMS}^{40}$ was used to assess body change behaviours. Seven items are rated on a 6-point Likert scale $(1=$ always and $6=$ never $)$, and total scores range from 7 to 42 . As performed for the oriented body image factor of the DMS, the scores for each item were inverted to calculate the final score.

Disordered eating. A simplified self-reporting questionnaire, adapted and tested for the Brazilian context, was used to evaluate disordered eating ${ }^{41}$. The questionnaire is composed of two questions and investigates the frequency of overeating/binge eating and the use of methods to control weight gain and potential compensatory mechanisms for excessive food intake such as induced vomiting, use of laxatives and diuretics, and restrictive diet and fasting ${ }^{41}$. The construct was standardized by transforming the answer options into a 4-point Likert scale ${ }^{42}$ to enable screening of disordered eating against the other questionnaires used in this study, which are ordinal (Likert scale): never $=1$; less than once a week $=2 ;$ once a week $=3 ;$ twice a week or more $=4$.

\section{Procedures}

After evaluating institutions that were potentially interested in participating in this research (as previously mentioned by contacting associated researchers), the academic departments of the respective universities were contacted, the research objectives were outlined, and professors were invited to participate in data collection. Data collection was performed during class time. The participants were informed of the study objectives and all data acquisition procedures. The author's Institutional Research Ethics Committee approved the study, and all participants signed an informed consent form.

\section{Data analysis}

Data regarding racial/ethnic background, socioeconomic status and anthropometric data were expressed as relative frequencies. Scores obtained from the questionnaires were presented as means and standard deviations. Analyses of the skewness and kurtosis were performed to determine the univariate and multivariate distributions $\mathrm{s}^{31}$. Mahalanobis distance $\left(\mathrm{D}^{2}\right)$ and VIF (Variance Inflation Factor) values were used to test for the presence of outliers and multicollinearity, respectively $y^{31,43}$. The Pearson correlation coefficient was used to test the association between variables $\left(r_{\text {pearson }}\right)$, while the internal consistency was determined using Cronbach's alpha coefficient $(\alpha)$, where a coefficient of .70 or greater is considered acceptable ${ }^{44}$. Correlations of .20 , .40 , and .60 were considered small, moderate, and strong, respectively ${ }^{45}$.

The proposed model (Figure 1) was evaluated using Structural Equation Modelling with the Maximum Likelihood estimation method ${ }^{31}$. Goodness of fit was determined using the following test ${ }^{31,43}$ : Chi-Square $\left(\chi^{2}\right)$, Corrected ChiSquare $\left(\chi^{2} / d f\right)$, Comparative Fit Index (CFI), Parsimony Comparative Fit Index (PCFI), and Root Mean Square Error of Approximation (RMSEA). The following values were considered acceptable $^{43}: \chi^{2}$ (the lower, the better; $\mathrm{p}>.05$ ), $\chi^{2} / d f$ (less than 5), CFI (greater than .80), PCFI (greater than .60), and RMSEA (between .05 and .10).

The model was refined by respecifying it using modification indices (Lagrange Multipliers) with values greater than $11^{31,43}$. The local goodness of fit was determined via factor weighting $(\lambda)$ and assessing the reliability of individual items, whereas the significance of causal paths was measured by performing a Z-test of critical ratios $^{31,43}$. Non-significant paths were not referenced in the final model.

A descriptive and inferential analysis was performed using the Statistical Package for Social Sciences version 21.0 (SPSS Inc., Chicago, United States), adopting a 5\% significance level $(\mathrm{p}<.05)$. Structural Equation Modelling was performed 


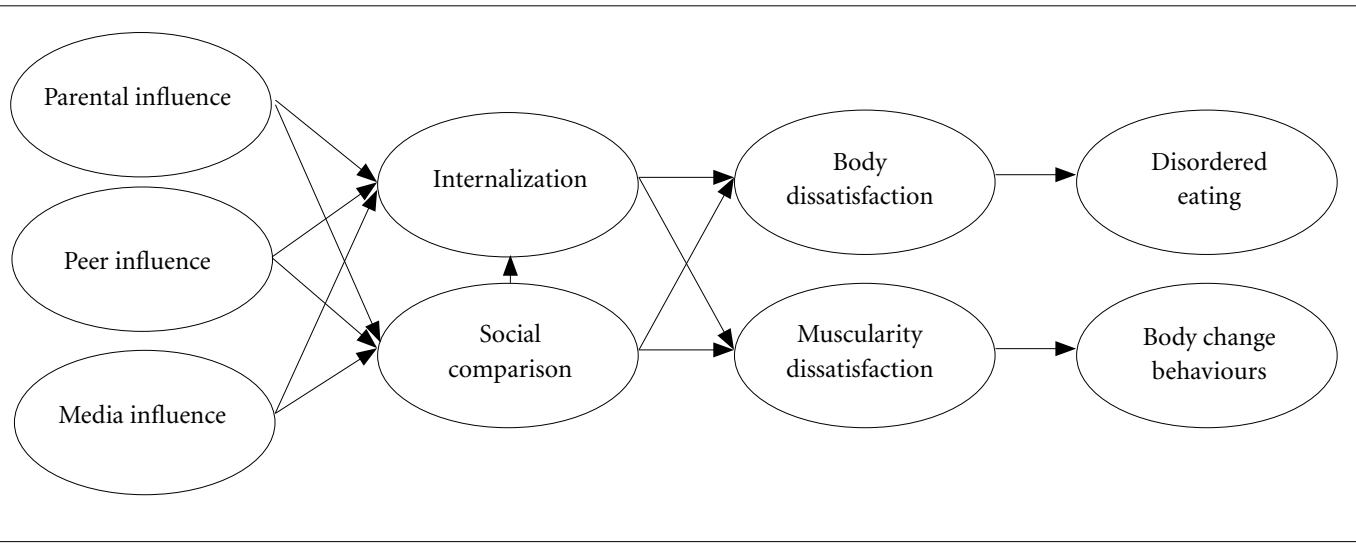

Figure 1. Tripartite Influence Model of disordered eating and body change behaviours among Brazilian male university students.

using the statistical software package Analysis of Moment Structures (AMOS) version 21.0.

\section{Results}

Seven hundred seven $(\mathrm{N}=707)$ Brazilian male university students participated in this study. The racial/ethnic background of the participants was $54.46 \%$ white, $33.56 \%$ dark skinned, $8.91 \%$ black and $3.07 \%$ multi-racial. Approximately two thirds of the sample $(61.67 \%)$ were normal weight, $29 \%$ overweight, $6.08 \%$ obese and only $3.25 \%$ underweight. In terms of socioeconomic family status, most participants reported being middle class $(76.81 \%)$, whereas $10.18 \%$ and $13.01 \%$ reported they were upper and lower class, respectively.

Means, SDs, and internal consistencies of the applied instruments are presented in Table 1. All measuring instruments exhibited satisfactory internal consistency. Analyses of the skewness and kurtosis indicated multivariate normality of the data. The VIF values were less than five, which indicates an absence of multicollinearity.

All latent variables were correlated (Table $2)$. Significant moderate correlations $\left(r_{\text {pearson }} \geq\right.$ .40) were identified between: Parental influences and Peer influences, Media influences and Internalization, Internalization and Body change behaviours, Internalization and Muscularity dissatisfaction, Social comparison and Muscularity dissatisfaction, Social comparison and Body change behaviours, Muscularity dissatisfaction and Body change behaviours, and Body dissatisfaction and Disordered eating. A strong correla- tion was identified between Internalization and Social comparison $\left(\mathrm{r}_{\text {pearson }}=.65, \mathrm{p}=.001\right)$.

Structural Equation Modelling indicated a poor fit of the proposed model $\left(\chi^{2}(3177)=\right.$ $11789.509, \mathrm{p}=.0001, \chi^{2} / d f=3.71, \mathrm{CFI}=.77, \mathrm{PCFI}$ $=.74, \mathrm{RMSEA}=.063[90 \% \mathrm{CI}=.062-.064]) . \mathrm{In}$ addition, in analysing the causal paths, three were not statistically significant: Parental influences $\rightarrow$ Social comparison, Peer influences $\rightarrow$ Internalization and Body dissatisfaction $\rightarrow$ Disordered eating. The model was re-specified, removing non-significant paths. After analysis, the adjustment indexes indicated an improvement in the model fit $\left(\chi^{2}(2790)=10548.421 ; \mathrm{p}=.0001 ; \chi^{2} /\right.$ $d f=3.78$; CFI $=.79 ;$ PCFI $=.75 ;$ RMSEA $=.064$ [90\%CI $=.062-.065])$. The $\chi^{2}$ value decreased, and increases in the CFI and PCFI were identified. The $\chi^{2} / d f$ value and RMSEA remained adequate $^{43}$. All causal paths were significant (Table $3)$. The local goodness of fit was adequate, with all $\lambda$ greater than $.40^{31,43}$. The Fitted Tripartite Influence Model with regression weights among Brazilian male university students are presented in Figure 2.

\section{Discussion}

This study aimed to evaluate the Tripartite Influence Model for Brazilian male university students. The importance of this study is emphasized by the need to better understand the aetiology and maintenance of body image disturbance and disordered eating to illuminate potential intervention points ${ }^{2,6}$. The importance attributed to physical appearance in the Brazilian population 
must be highlighted ${ }^{27,29,30}$, as well as the need to consider cultural aspects regarding body image disturbances and eating disorder ${ }^{26,46}$.
Our results indicated that the proposed model is adequate. Nearly all indexes exhibited satisfactory values. The re-specified model showed

Table 1. Descriptive analysis (mean and standard deviation) and internal consistency of the total number of participants $(\mathrm{N}=707)$.

\begin{tabular}{lcr}
\hline \multicolumn{1}{c}{ Variables } & $\begin{array}{c}\text { Internal consistency } \\
\text { (Cronbach's } \boldsymbol{\alpha})\end{array}$ & $\begin{array}{c}\text { Descriptive } \\
\text { Mean (SD) }\end{array}$ \\
\hline TIS (Parental influence) & .87 & $34.92(10.85)$ \\
TIS (Peer influence) & .89 & $27.51(8.46)$ \\
TIS (Media influence) & .81 & $23.20(7.56)$ \\
SATAQ-3 (Internalization) & .91 & $27.73(10.49)$ \\
MBCQ (Social comparison) & .93 & $13.70(6.40)$ \\
BSQ-8 (Body dissatisfaction) & .84 & $16.16(7.92)$ \\
DMS (Muscularity dissatisfaction) & .91 & $16.12(7.51)$ \\
DMS (Body change behaviours) & .84 & $13.97(7.38)$ \\
Disordered eating & .70 & $6.21(1.63)$ \\
\hline SD:St
\end{tabular}

SD: Standard Deviation; TIS: Tripartite Influence Scale; SATAQ-3: Sociocultural Attitudes Towards Appearance Questionnaire-3; MBCQ: Male Body Checking Questionnaire; BSQ-8: Body Shape Questionnaire short version; DMS: Drive for Muscularity Scale.

Table 2. Correlation between latent variables of the Tripartite Influence Model of disordered eating and body change behaviours among Brazilian male university students $(\mathrm{N}=707)$.

\begin{tabular}{|c|c|c|c|c|c|c|c|c|c|}
\hline Variables & 1 & 2 & 3 & 4 & 5 & 6 & 7 & 8 & 9 \\
\hline 1. TIS (Parental influences) & - & & & & & & & & \\
\hline 2. TIS (Peer influences) & .42 & - & & & & & & & \\
\hline 3. TIS (Media influences) & .26 & .37 & - & & & & & & \\
\hline 4. SATAQ-3 (Internalization) & .24 & .28 & .40 & - & & & & & \\
\hline 5. MBCQ (Social comparison) & .17 & .30 & .29 & .65 & - & & & & \\
\hline 6. BSQ-8 (Body dissatisfaction) & .29 & .38 & .37 & .32 & .24 & - & & & \\
\hline 7. DMS (Muscularity dissatisfaction) & .21 & .28 & .27 & .56 & .50 & .37 & - & & \\
\hline 8. DMS (Body change behaviours) & .25 & .25 & .27 & .40 & .45 & .14 & .50 & - & \\
\hline 9. Disordered eating & .17 & .23 & .19 & .14 & .19 & .47 & .14 & .12 & - \\
\hline
\end{tabular}

All correlations are significant at .001 level (two-tailed). TIS: Tripartite Influence Scale; SATAQ-3: Sociocultural Attitudes Towards Appearance Questionnaire-3; MBCQ: Male Body Checking Questionnaire; BSQ-8: Body Shape Questionnaire short version; DMS: Drive for Muscularity Scale.

Table 3. Non-standardized estimates and significance of paths between latent variables of the Tripartite Influence Model of disordered eating and body change behaviours among Brazilian male university students $(\mathrm{N}=707)$.

\begin{tabular}{|c|c|c|c|c|}
\hline Paths & $\boldsymbol{\beta}$ & SE & CR & p \\
\hline Social comparison $\leftarrow$ Peer influences & .393 & .069 & 5.704 & $.0001^{\star}$ \\
\hline Social comparison $\leftarrow$ Media influences & .285 & .085 & 3.370 & $.0001^{\star}$ \\
\hline Internalization $\leftarrow$ Parental influences & .116 & .056 & 2.082 & $.037^{\star}$ \\
\hline Internalization $\leftarrow$ Media influences & .261 & .063 & 4.173 & $.0001^{\star}$ \\
\hline Internalization $\leftarrow$ Social comparison & .484 & .034 & 14.106 & $.0001^{\star}$ \\
\hline Body dissatisfaction $\leftarrow$ Social comparison & .120 & .058 & 2.082 & $.037^{\star}$ \\
\hline Muscularity dissatisfaction $\leftarrow$ Social comparison & .585 & .083 & 7.031 & $.0001^{*}$ \\
\hline Body dissatisfaction $\leftarrow$ Internalization & .403 & .065 & 6.159 & $.0001^{\star}$ \\
\hline Muscularity dissatisfaction $\leftarrow$ Internalization & .649 & .094 & 6.942 & $.0001^{\star}$ \\
\hline Body change behaviours $\leftarrow$ Muscularity dissatisfaction & .233 & .021 & 10.880 & $.0001^{\star}$ \\
\hline
\end{tabular}

$\beta=$ estimate; $\mathrm{SE}=$ standardized error; $\mathrm{CR}=$ critical ratio; $\mathrm{p}=\mathrm{p}$ value. ${ }^{\star} \mathrm{p}<.05$. 


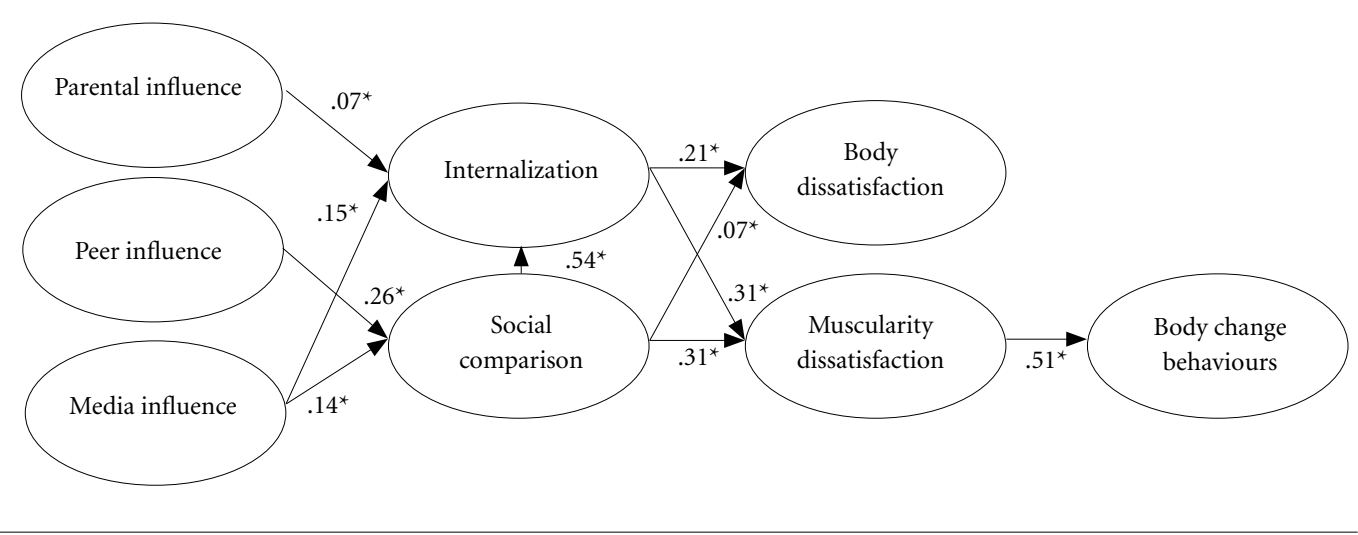

Figure 2. Fitted Tripartite Influence Model of disordered eating and body change behaviours among Brazilian male university students.

${ }^{\star}$ Regression weights $(\mathrm{p}<.05)$.

an adequate fit with substantial improvements in the adjustment indexes, and all causal paths were significant. However, the $\chi^{2}$ test was also significant, and the CFI value was slightly less than .80 $(\mathrm{CFI}=.79)$.

With regards to the $\chi^{2}$ test, it has been established that this test is sensitive to the sample size $^{31,43}$. Therefore, we used the absolute index $\left(\chi^{2} / d f\right)$, which indicated an adequate value (less than 5$)^{43}$. Regarding the CFI, its parsimony index (PCFI) was taken into account. It performs a correction of the relative index (CFI) by a penalty factor associated with the complexity of the proposed theoretical model ${ }^{43}$. The CFI is independent of the sample size; however, it is penalized by the model's complexity ${ }^{43}$, which is high in the case of the present research. Thus, the use of the PCFI corrects the reduction in the CFI, taking into account the degrees of freedom of the test model and the independent model. Therefore, based on this discussion, the fitted Tripartite Influence Model of disordered eating and body change behaviours among Brazilian male university students was considered adequate.

Similar to the original model proposed by Thompson et al. ${ }^{7}$ and the model proposed by Karazsia and Crowther ${ }^{20}$, the model tested in the present study is considered a full mediation model. The conducted analyses did not indicate improvements in the model adjustment through the inclusion of direct paths between sociocultural influences (parental, peer and media) and Body dissatisfaction, Muscularity dissatisfaction or Body change behaviours. In this sense, Inter- nalization and Social comparison are full mediating variables. In other words, they explain "how" or "why" sociocultural influences predict or cause body dissatisfaction and muscularity dissatisfaction.

Regarding Peer influences, a non-significant pathway of this variable with Internalization was identified. The way in which peers lead to Internalization occurs indirectly through the Social comparison. Carvalho et al. ${ }^{8}$ reported a similar result in a study with Brazilian women. According to the authors, this result indicates a specific characteristic in relation to the way in which Brazilian women internalize social ideals.

The authors also suggest the influence of the measurement tool used to assess Internalization ${ }^{8}$. The SATAQ- $3^{37}$ internalization index was developed with a focus on media influence on body image. Thus, a greater association between Media influences and Internalization is justified in relation to the other sociocultural variables. Moreover, our results showed a higher correlation between Media influences and Internalization $\left(\mathrm{r}_{\text {pearson }}=.40, \mathrm{p}=.001\right)$ than the correlations between Internalization and Parental influences $\left(\mathrm{r}_{\text {pearson }}=.24, \mathrm{p}=.001\right)$ and Peer influences $\left(\mathrm{r}_{\text {pearson }}\right.$ $=.28, \mathrm{p}=.001)$. Thus, we believed that the phenomenon observed in Brazilian women in relation to Internalization ${ }^{8}$ also occurs among male university students in this country.

Another non-significant causal pathway was identified between Parental influences and Social Comparison. The reasons this causal path was not significant in the Brazilian population 
remain unclear. Again, it is possible that the measurement instrument contributed to this result. The parental influences subscale of the Tripartite Influence Scale ${ }^{36}$ has items that refer to the direct and indirect influences of parents on the need for weight loss and diets. Considering that the ideal body for men is featured by a figure with a muscular body, it is possible that these parental messages do not interfere in the way Brazilian male university students adhere to Social comparison. To confirm these hypotheses future studies should invest in implementing instruments with greater ability to capture the male peculiarities with respect to their bodies. For example, the SATAQ- $4^{47}$ is a promising instrument in this context. However, it still has not had its validity and reliability confirmed for the Brazilian population.

An important aspect to consider is the finding that previous studies ${ }^{12,20}$ have evaluated sociocultural influences as a unique latent variable. Specifically, parents, peers and media were used together to create the latent variable "sociocultural influences". The assertion that sociocultural factors lead to Internalization and Social comparison may not be true if the operationalization of the variables is performed jointly. For example, it is possible that Parental influences and Media influences act incisively on Internalization when evaluated together, and Peer influences do not contribute to the causal path. However, if "sociocultural influence" is operationalized by joining the items of the three factors, the non-influence of the peers may be hidden. For this reason, the three sociocultural factors were used separately in the present research to enable evaluating the influence of each factor on the Internalization and Social comparison.

However, of all the obtained results, what is most striking is the finding that the Body dissatisfaction remained in the fitted model. It is highlighted that (to the best of our knowledge) this investigation is the first study that included both Body dissatisfaction $\rightarrow$ Disordered eating and Muscularity dissatisfaction $\rightarrow$ Body change behaviour paths in a single theoretical model based on the Tripartite Influence Model. According to some authors, male body image concerns have been neglected for years, and after accepting the fact that these subjects suffer body image disturbances, the focus was exclusively on muscularity ${ }^{4,13}$. However, the amount of adipose tissue, as well as body shape are important aspects for men because in order to reach a defined body, it is necessary to reduce the amount of body fat ${ }^{13}$. As previously discussed, the drive for thinness and the drive for muscularity are not mutually exclusive constructs ${ }^{18}$. Therefore, our results indicate that body dissatisfaction is an important issue for Brazilian male university students because it is potentially linked to the pursuit of a muscular body.

Nevertheless, there was a non-significant path between Body dissatisfaction and Disordered eating; thus, the latter latent variable was removed from the final model. Strother et al. ${ }^{15}$ noted that male eating disorders remain misunderstood. In order to better understand the development of eating disorders in men, it is necessary to move away from the logic of what occurs in women ${ }^{15}$. The relationship between men and food appears to be different from that observed in women ${ }^{15}$. Our results reinforce the idea that the phenomenon of eating disorders in men is complex and therefore requires measurement instruments capable of capturing the peculiarities of individuals of this sex in relation to disordered eating behaviours associated with the pathology of eating disorders.

The present research provides important information and expands the debate regarding body image disturbances, disordered eating and the body change behaviours among men. It is also worth noting that the study is important for providing a specific theoretical model for Brazilian male university students. For example, the results indicate that Parental influences do not lead to Social comparison and Peer influences do not lead to Internalization. Internalization and Social comparison are important factors for the development of body dissatisfaction and muscularity dissatisfaction among men. Furthermore, Body dissatisfaction proves to be important for Brazilian young men, even though it has not led to disordered eating. Intervention programmes should consider these associations.

There are limitations to this study that are important to acknowledge. First, the cross-sectional design does not enable a causality analysis. It is possible to delineate hypothetical causal relationships between the independent (exogenous) and dependent (endogenous) variables ${ }^{31,43}$ through Structural Equation Modelling. Thus, the method simulates the causal relationship through the combination of statistical techniques such as factor analysis and path analysis; however, it does not allow for classic causal analyses, such as those verified in longitudinal designs. Second, although male university students from different regions of Brazil were evaluated, we em- 
ployed a sample selection by convenience. Finally, measurement instruments, although mostly psychometrically evaluated for the Brazilian male population, remain focused on the drive for thinness, such as the Tripartite Influence Scale ${ }^{36}$ and SATAQ- $3^{37}$. However, the SATAQ-3, for example, has been used in other studies with the male population $^{3,12,20}$.
Given the complexity and multifaceted nature of body image and disordered eating, further research is merited to test different models that include explanatory variables which were not considered in this study. The specificities of men with respect to these two constructs may have other intervening variables which have not been previously tested.

\section{Collaborations}

PHB Carvalho and MEC Ferreira participated in all stages of the research, considering data delineation, analysis and interpretation; writing of the article and approval of the version to be published. 


\section{References}

1. Stice E. A prospective test of the dual-pathway model of bulimic pathology: Mediating effects of dieting and negative affect. J Abnorm Psychol 2001; 110(1):124135.

2. Stice E. Risk and maintenance factors for eating pathology: a meta-analytic review. Psychol Bull 2002; 128(5):825-848.

3. Dakanalis A, Zanetti AM, Riva G, Colmegna F, Volpato C, Madeddu F, Clerici M. Male body dissatisfaction and eating disorder symptomatology: Moderating variables among men. J Health Psychol 2015; 20(1):8090.

4. Cafri G, Thompson JK, Ricciardelli L, McCabe M, Smolak L, Yesalis C. Pursuit of the muscular ideal: Physical and psychological consequences and putative risk factors. Clin Psychol Rev 2005; 25(2):215-239.

5. Pope HG, Khalsa JH, Bhasin S. Body image disorders and abuse of anabolic-androgenic steroids among men. JAMA 2017; 317(1):23-24.

6. Cash TF, Smolak L. Body image: a handbook of science, practice, and prevention. 2nd ed. New York: Guilford Press; 2011.

7. Thompson JK, Heinberg LJ, Altabe M, Tantleff-Dunn S. Exacting beauty: theory, assessment, and treatment of body image disturbance. Worcester: American Psychological Association; 1999.

8. Carvalho PHB, Alvarenga MS, Ferreira MEC. An etiological model of disordered eating behaviors among Brazilian women. Appetite 2017; 116:164-172.

9. Tiggemann M. Sociocultural perspectives on human appearance and body image. In: Cash TF, Smolak L, editors. Body image: a handbook of science, practice, and prevention. 2nd ed. New York: Guilford Press; 2011.p. 12-9.

10. Karazsia BT, van Dulmen MH, Wong K, Crowther $\mathrm{JH}$. Thinking meta-theoretically about the role of internalization in the development of body dissatisfaction and body change behaviors. Body Image 2013; 10(4):433-441.

11. Festinger L. A theory of social comparison processes. Hum Relations 1954; 7(2):117-140.

12. Karazsia BT, Crowther JH. Sociocultural and psychological links to men's engagement in risky body change behaviors. Sex Roles 2010; 63(9-10):747-756.

13. Cafri G, Thompson JK. Measuring male body image: A review of the current methodology. Psychol Men Masculinity 2004; 5(1):18-29.

14. Thompson JK, Cafri G. The muscular ideal: psychological, social, and medical perspectives. Worcester: American Psychological Association; 2007.

15. Strother E, Lemberg R, Stanford SC, Turberville D. Eating disorders in men: underdiagnosed, undertreated, and misunderstood. Eat Disord 2012; 20(5):346355.

16. Edwards C, Tod D, Molnar G. A systematic review of the drive for muscularity research area. Int Rev Sport Exerc Psychol 2014; 7(1):18-41.

17. McCreary DR, Sasse DK. An exploration of the drive for muscularity in adolescent boys and girls. J Am Coll Health 2000; 48(6):297-304.
18. Kelley CCG, Neufeld JM, Musher-Eizenman DR. Drive for thinness and drive for muscularity: Opposite ends of the continuum or separate constructs? Body Image 2010; 7(1):74-77.

19. Murray SB, Rieger E, Hildebrandt T, Karlov L, Russell J, Boon E, Dawson RT, Touyz SW. A comparison of eating, exercise, shape, and weight related symptomatology in males with muscle dysmorphia and anorexia nervosa. Body Image 2012; 9(2):193-200.

20. Karazsia BT, Crowther JH. Social body comparison and internalization: Mediators of social influences on men's muscularity-oriented body dissatisfaction. Body Image 2009; 6(2):105-112.

21. Smolak L, Murnen SK, Thompson JK. Sociocultural influences and muscle building in adolescent boys. Psychol Men Masculinity 2005; 6(4):227-239.

22. Halliwell E, Harvey M. Examination of a sociocultural model of disordered eating among male and female adolescents. Br J Health Psychol 2006; 11(2):235-248.

23. Jones DC, Bain N, King S. Weight and muscularity concerns as longitudinal predictors of body image among early adolescent boys: A test of the dual pathways model. Body Image 2008; 5(2):195-204.

24. Van den Berg P, Paxton SJ, Keery H, Wall M, Guo J, Neumark-Sztainer D. Body dissatisfaction and body comparison with media images in males and females. Body Image 2007; 4(3):257-268.

25. Fortes LS, Filgueiras JF, Oliveira FC, Almeida SS, Ferreira MEC. Modelo etiológico dos comportamentos de risco para os transtornos alimentares em adolescentes brasileiros do sexo feminino. Cad Saude Publica 2016; 32(4):e000024115.

26. Rodgers R, Chabrol H, Paxton, SJ. An exploration of the tripartite influence model of body dissatisfaction and disordered eating among Australian and French college women. Body Image 2011; 8(3):208-215.

27. Silva DAS, Nahas MV, Sousa TF, Del Duca GF, Peres KG. Prevalence and associated factors with body image dissatisfaction among adults in southern Brazil: a population-based study. Body Image 2011; 8(4):427431.

28. Reis JAD, Silva Júnior CRR, Pinho LD. Factors associated with the risk of eating disorders among academics in the area of health. Rev Gaucha Enferm 2014; 35(2):73-78.

29. Rocha E, Frid M. In perfect shape media representations of women's health in Brazil. Mediterr J Soc Sci 2013; 4(9):474-481.

30. Edmonds A. 'The poor have the right to be beautiful': cosmetic surgery in neoliberal Brazil. J R Anthropol Inst 2007; 13(2):363-381.

31. Westland JC. Lower bounds on sample size in structural equation modeling. Electronic Commerce Res Appl 2010; 9(6):476-487.

32. Kline RB. Principles and practice of structural equation modelling. 3rd ed. New York: Guilford Press; 2011.

33. Instituto Brasileiro de Geografia e Estatística (IBGE). Características étnico-raciais da população: Classificações e identidades. Rio de Janeiro: IBGE; 2013. 
34. World Health Organization (WHO). Body mass index classification: Report of a WHO consultation on obesity. Geneva: WHO; 1995.

35. Associação Brasileira de Empresas de Pesquisa (ABEP). Critério de Classificação Econômica Brasil 2014 [Internet]. São Paulo: ABEP; 2014 [cited 2014 Feb 5]. Available from: http://www.abep.org/criterio-brasil

36. Amaral ACS, Ferreira MEC, Scagliusi FB, Costa LS, Cordas TA, Conti MA. Psychometric evaluation of the Tripartite Influence Scale. Psicol Reflex Crit 2013, 26(2):213-221.

37. Amaral ACS, Ribeiro MS, Conti MA, Ferreira CS, Ferreira MEC. Psychometric evaluation of the Sociocultural Attitudes Towards Appearance Questionnaire-3 among Brazilian young adults. Span J Psychol 2013; 16(e94):1-10.

38. Carvalho PHB, Conti MA, Ribeiro MS, Amaral ACS, Ferreira MEC. Psychometric assessment of the Male Body Checking Questionnaire (MBCQ). Psicol Reflex Crit 2014; 27(4):700-709.

39. Silva WR, Dias JCR, Maroco J, Campos JADB. Confirmatory factor analysis of different versions of the Body Shape Questionnaire applied to Brazilian university students. Body Image 2014; 11(4):384-390

40. Campana ANNB, Tavares MCGCF, Swami V, Silva D. An examination of the psychometric properties of Brazilian Portuguese translations of the Drive for Muscularity Scale, the Swansea Muscularity Attitudes Questionnaire, and the Masculine Body Ideal Distress Scale. Psychol Men Masculinity 2013; 14(4):376-388.

41. Ferreira JEDS, Veiga GVD. Test-retest reliability of a simplified questionnaire for screening adolescents with risk behaviors for eating disorders in epidemiologic studies. Rev Bras Epidemiol 2008; 11(3):393-401.

42. Ortega-Luyando M, Alvarez-Rayón G, Garner DM, Amaya-Hernández A, Bautista-Díaz ML, Mancilla-Díaz JM. Systematic review of disordered eating behaviors: Methodological considerations for epidemiological research. Rev Mex Transtornos Alimentarios 2015; 6(1):51-63.

43. Maroco J. Análise de Equações Estruturais: Fundamentos teóricos, softwares e aplicações [Analysis of Structural Equations: Theoretical foundations, software and applications]. 2nd ed. Pêro Pinheiro: Report Number; 2014.

44. Nunnally JC. Psychometric theory. 2nd ed. New York: McGraw-Hill; 1978.

45. Tabachnick BG, Fidell LS. Using multivariate statistics. 5th ed. Boston: Allyn \& Bacon; 2007.
46. Swami V, Frederick DA, Aavik T, Alcalay L, Allik J, Anderson D, Andrianto S, Arora A, Brännström A, Cunningham J, Danel D, Doroszewicz K, Forbes GB, Furnham A, Greven CU, Halberstadt J, Hao S, Haubner T, Hwang CS, Inman M, Jaafar JL, Johansson J, Jung J, Keser A, Kretzschmar U, Lachenicht L, Li NP, Locke K, Lönnqvist J-E, Lopez C, Loutzenhiser L, Maisel NC, McCabe MP, McCreary DR, McKibbin WF, Mussap A, Félix Neto, Nowell C, Alampay LP, Pillai SK, Pokrajac-Bulian A, Proyer RT, Quintelier K, Ricciardelli LA, Rozmus-Wrzesinska M, Ruch W, Russo T, Schütz A, Shackelford TK, Shashidharan S, Simonetti F, Sinniah D, Swami M, Vandermassen G, van Duynslaeger M, Verkasalo M, Voracek M, Yee CK, Zhang EX, Zhang X, Zivcic-Becirevic I. The attractive female body weight and female body dissatisfaction in 26 countries across 10 world regions: Results of the International Body Project I. Pers Soc Psychol Bull 2010; 36(3):309-325.

47. Schaefer LM, Burke NL, Thompson JK, Dedrick, RF, Heinberg, LJ, Calogero RM, Bardone-Cone AM, Higgins MK, Frederick DA, Kelly M, Anderson DA, Schaumberg K, Nerini A, Stefanile C, Dittmar H, Clark E, Adams Z, Macwana S, Klump KL, Vercellone AC, Paxton SJ, Swami V. Development and validation of the Sociocultural Attitudes Towards Appearance Questionnaire-4 (SATAQ-4). Psychol Assess 2015; 27(1):54-67.

Article submitted 02/08/2018

Approved 15/02/2019

Final version submitted 17/02/2019 
